\title{
PREPARATIONS OF THE TUMOR NECROSIS FACTOR: CHARACTERISTICS, PRODUCTION METHODS AND MODIFICATION
}

\author{
E. Kharchenko, O. Skrotska, Yu. Penchuk, O. Bodnar \\ National University of Food Technologies
}

\begin{tabular}{|c|c|}
\hline Key words: & ABSTRACT \\
\hline $\begin{array}{l}\text { Tumor necrosis factor } \\
\text { Recombinant drug } \\
\text { (preparation) } \\
\text { Producer } \\
\text { Modification }\end{array}$ & $\begin{array}{l}\text { The paper presents data about the biological properties of the } \\
\text { tumor necrosis factor (TNF) and drugs based on it, which are } \\
\text { used in medical practice to combat cancer. The preparates for } \\
\text { scientific research based on recombinant TNF have also been } \\
\text { described. The brief information about the possibilities of }\end{array}$ \\
\hline $\begin{array}{l}\quad \text { Article history: } \\
\text { Received } 03.11 .2017 \\
\text { Received in revised form } \\
24.11 .2017 \\
\text { Accepted } 15.12 .2017\end{array}$ & $\begin{array}{l}\text { obtaining TNF using unicellular pro- (Escherichia coli) and } \\
\text { eukaryotes (Saccharomyces cerevisiae, Pichia pastoris) is } \\
\text { given. The TNF synthesis inducers (bacterial lipopolysaccha- } \\
\text { rides, phytohemaglutenin, antigens of various organisms) that } \\
\text { are used in the cultivation of immunocompetent animals or }\end{array}$ \\
\hline $\begin{array}{l}\text { Corresponding author: } \\
\text { E. Kharchenko } \\
\text { E-mail: } \\
\text { npnuht@ukr.net }\end{array}$ & $\begin{array}{l}\text { human mononuclear cells are characterized. The possibilities } \\
\text { of TNF modification to improve its biological properties, } \\
\text { increase activity and reduce toxicity, create TNF nano- } \\
\text { composites with antibiotics, antibody fragments, and metal } \\
\text { nanoparticles, disadvantages of the use of polyethylene glycol } \\
\text { for modification of TNF have also been presented. }\end{array}$ \\
\hline
\end{tabular}

DOI: $10.24263 / 2225-2924-2017-23-6-7$

\section{ПРЕПАРАТИ ФАКТОРА НЕКРОЗУ ПУХЛИН: ХАРАКТЕРИСТИКА, СПОСОБИ ОТРИМАННЯ ТА МОДИФІКАЦІї}

\author{
С.В. Харченко, О.І. Скроцька, Ю.М. Пенчук, О.В. Боднар \\ Національний університет харчових технологій
}

У статті узагальнено дані про біологічні властивості фактора некрозу пухлин (ФНП) $і$ препаратів на його основі, які застосовують у лікарській практищі для боротьби з раковими захворюваннями. Охарактеризовано препарати для наукових досліджень на основі рекомбінантного ФНП. Наведено коротку інформацію про можливості отримання ФНП за допомогою одноклітинних про- (Escherichia coli) та еукаріom (Saccharomyces cerevisiae, Pichia pastoris). Описано індуктори синтезу ФНП (бактеріальні ліпополісахариди, фітогемаглютенін, антигени різних організмів), які використовують при культивуванні імунокомпетентних тваринних або людських мононуклеарних клітин. Визначено можливості модифікації ФНП для покращення його біологічних властивостей, підвищення активності та зменшення 
токсичності, створення нанокомпозитів ФНП з антибіотиками, фрагментами антитіл, наночастками металів, а також недоліки використання поліетиленгліколю для модифікаиії ФНП.

Ключові слова: фактор некрозу пухлин, рекомбінантний препарат, продуиент, модифікація.

Постановка проблеми. Пошук ефективних засобів лікування злоякісних новоутворень $\epsilon$ доволі актуальним завданням сьогодення. Нині увагу дослідників все частіше привертає цитокінотерапія онкологічних захворювань, зокрема застосування фактора некрозу пухлин (ФНП) для лікування раку. Вибір ФНП пов'язаний з його вибірковою здатністю призупиняти ріст і викликати лізис злоякісних клітин, геморагічний некроз пухлин та активувати імунний протипухлинний імунітет.

ФНП володіє плейотропним ефектом і викликає експресію адгезивних молекул як на фагоцитах, так і на клітинах ендотелію судин. Останні виконують роль сполучної ланки між кров'ю і тканинами, беручи безпосередню участь у регуляції транспорту лейкоцитів і функціонуванні системи згортання крові. Також ФНП як ключовий регулятор запального та імунологічного процесів відіграє важливу роль у патогенезі захворювань внутрішніх органів, нервової й ендокринної систем, очей, шкіри, суглобів тощо [1].

Біологічні ефекти ФНП залежать від його концентрації. У низьких концентраціях цитокін діє в місці індукції, як пара- і аутокринний регулятор аутоімунних реакції - при травмах або інфекціях. ФНП є основним стимулятором для нейтрофілів і ендотеліальних клітин, адгезії і подальшої міграції лейкоцитів, проліферації фібробластів і ендотелію при загоєнні ран. У помірних концентраціях ФНП, потрапляючи в кров, діє як гормон, що володіє пірогенним ефектом, стимулюючи утворення фагоцитів, посилює згортання крові, знижує апетит, $є$ важливим фактором розвитку кахексії при таких хронічних захворюваннях, як туберкульоз і рак [2].

Цитотоксичну дію ФНП на пухлинні клітини пов'язують 3 деградацією ДНК і порушенням функціонування мітохондрій. Літичний ефект ФНП посилюється за наявності інтерферону. Один із механізмів синергічної дії вказаних цитокінів полягає в посиленні експресії рецепторів до ФНП на пухлинних клітинах під впливом інтерферонів.

Таким чином, ФНП виконує роль не тільки ефекторного медіатора цитотоксичності, забезпечуючи лізис злоякісних клітин-мішеней, але й бере участь у регуляції різних фізіологічних і патологічних процесів в організмі. Подальше вивчення біологічної активності ФНП, особливо механізмів іiі реалізації, слугуватиме підгрунтям для детальної розробки показань і методик клінічного застосування цитотоксичного поліпептиду не тільки при лікуванні хворих із злоякісними пухлинами, а й в інших галузях клінічної медицини, а також для пошуків нових лікарських засобів, що регулюють його продукцію в організмі.

Мета дослідження: на основі огляду літературних джерел проаналізувати сучасні препарати фактора некрозу пухлин, їх способів отримання та можли- 
вих модифікацій ФНП, що дасть змогу підвищити біологічну активність цитокіну і знизити його токсичність.

Викладення основних результатів дослідження. Нині в онкології застосовують ряд клінічних лікарських препаратів на основі рекомбінантних цитокінів, таких як ФНП, інтерлейкіни (ІЛ), фактора, що інгібує міграцію фагоцитів (МІФ), інтерферонів (ІФН) тощо. Проте повністю досліджених препаратів на основі цитокінів, які пройшли всі стадії клінічного дослідження, відносно небагато, особливо тих, основою яких є рекомбінантний фактор некрозу пухлин. Препарати рекомбінантного ФНП (як лікарські засоби, так i ті, що призначені лише для наукових досліджень) випускаються у формі ліофілізованого порошку. У табл. 1 узагальнено дані про препарати на основі ФНП, що застосовуються в лікарській практиці.

Таблиия 1. Препарати рекомбінантного фактора некрозу пухлин

\begin{tabular}{|c|c|c|}
\hline $\begin{array}{c}\text { Назва препарату/фірма і } \\
\text { країна-виробник }\end{array}$ & Діюча речовина & Застосування \\
\hline $\begin{array}{c}\text { РЕФНОТ } \AA / \ll \text { Рефнот- } \\
\text { Фарм», Росія }\end{array}$ & $\begin{array}{c}\text { ФНП-тимозин альфа-1 } \\
\text { рекомбінантний }\end{array}$ & \multirow[b]{2}{*}{$\begin{array}{c}\text { Терапія раку молочної залози; в } \\
\text { комплексній терапії з } \\
\text { хіміопрепаратами. }\end{array}$} \\
\hline $\begin{array}{c}\text { Фактор некрозу пухлин } \\
\text { альфа (рчTNF } \alpha) / \\
\text { НДКТІ БАР ДНЦ ВБ } \\
\text { «Вектор», Росія }\end{array}$ & ФНП-альфа & \\
\hline $\begin{array}{c}\text { Лейкінферон/НДКТІ } \\
\text { БАР ДНЦ ВБ «Вектор», } \\
\text { Росія }\end{array}$ & $\begin{array}{l}\text { ІФН-альфа та інші } \\
\text { цитокіни (ФНП, ІЛ-1, } \\
\text { ІЛ-6 та ін.) }\end{array}$ & $\begin{array}{c}\text { Гострий гепатит В, хронічний } \\
\text { активний гепатит В, хронічний гепатит } \\
\text { С, гострі кондиломи, кліщовий } \\
\text { енцефаліт, тріхолейкоз, множинна } \\
\text { мієлома, неходжкінська лімфома, } \\
\text { шкірна Т-клітинна лімфома, саркома } \\
\text { Капоші хворих на СНІД, хронічний } \\
\text { мієлолейкоз, карцинома сечового } \\
\text { міхура, карцинома нирки, меланома, } \\
\text { респіраторний папіломатоз гортані, } \\
\text { первинний і вторинний тромбоцитоз, } \\
\text { перехідна форма хронічного } \\
\text { гранулоцитарного лейкозу і } \\
\text { мієлофіброзу, ретикулосаркома. } \\
\end{array}$ \\
\hline $\begin{array}{c}\text { Суперлімф/Центр } \\
\text { імунотерапії } \\
\text { «Иммунохелп», Росія }\end{array}$ & $\begin{array}{c}\text { Природний комплекс } \\
\text { імунопептидів } 3 \text { мол. } \\
\text { масою менше } 40 \text { кД з } \\
\text { активністю ряду } \\
\text { цитокінів (ФНП, МІФ, } \\
\text { ІЛ-1, ІЛ-6) }\end{array}$ & $\begin{array}{c}\text { Терапія захворювань різної етіології, } \\
\text { що супроводжуються запаленням і } \\
\text { порушенням репарації, а також } \\
\text { гострих хронічних запальних } \\
\text { захворювань, пов'язаних з розвитком } \\
\text { локального імунодефіциту. }\end{array}$ \\
\hline $\begin{array}{c}\text { Бефнорин/НДКТІ } \\
\text { БАР ДНЦ ВБ «Вектор», } \\
\text { Росія }\end{array}$ & $\begin{array}{l}\text { Рекомбінантний ФНП- } \\
\text { бета }\end{array}$ & $\begin{array}{l}\text { Імуностимулюючий, протипухлинний } \\
\text { та антиметастатичний засіб. }\end{array}$ \\
\hline
\end{tabular}

Крім зареєстрованих лікарських засобів на основі ФНП, нині ряд виробників випускають рекомбінантні препарати ФНП для наукових досліджень (табл. 2). Зокрема, США є одним із світових лідерів у виробництві і продажу 
рекомбінантних ФНП як комерційних препаратів для наукових цілей. Варто звернути увагу на те, що рекомбінантний ФНП отримують тільки завдяки культивуванню генетично модифікованих клітин. Для продукції ФНП використовують такі системи синтезу: прокаріотичні - на основі Escherichia coli, одноклітинні еукаріотичні - Saccharomyces cerevisiae та Pichia pastoris, перещеплювані культури еукаріотичних клітин - CHO (лінія клітин яєчника китайського хом’ячка, від англ. Chinese hamster ovary) [3-5].

Таблиия 2. Препарати рекомбінантного фактора некрозу пухлин для наукових досліджень

\begin{tabular}{|c|c|c|}
\hline Комерційна назва препарату & Виробник / країна & $\begin{array}{c}\text { Продуцент/ } \\
\text { чистота, } \%\end{array}$ \\
\hline $\begin{array}{c}\text { Recombinant Human Tumor } \\
\text { Necrosis Factor Alpha } \\
\text { (TNF-alpha) }\end{array}$ & Invitrogen Corporation / USA & E. coli/95\% \\
\hline Recombinant Human TNF- $\alpha$ & Bio-techne/R\&D Systems / USA & E. coli $/ 97 \%$ \\
\hline Recombinant Human TNF- $\alpha$ & BioVision Incorporated / USA & E. coli $>98 \%$ \\
\hline $\begin{array}{c}\text { Tumor Necrosis Factor- } \alpha, \text { Human, } \\
\text { Recombinant }\end{array}$ & Promega Corporation / USA & E. coli $>96 \%$ \\
\hline $\begin{array}{c}\text { Tumor Necrosis Factor-alpha (TNF- } \\
\alpha \text { ), Human (P. pastoris-expressed) }\end{array}$ & GenScript / China & P. pastoris $/>95 \%$ \\
\hline $\begin{array}{c}\text { T7539 (Tumor Necrosis Factor- } \alpha, \\
\text { recombinant) }\end{array}$ & $\begin{array}{c}\text { Sigma-Aldrich Chemie GmbH / } \\
\text { Germany }\end{array}$ & E. coli $>98 \%$ \\
\hline $\begin{array}{c}\text { Recombinant Human Tumor } \\
\text { Necrosis Factor-beta }\end{array}$ & ProSpec Bio / Germany & P. pastoris $/>97 \%$ \\
\hline $\begin{array}{c}\text { Human tumor necrosis factor-beta } \\
\text { (TNF-b) }\end{array}$ & BioWORLD / USA & E. coli $>99 \%$ \\
\hline
\end{tabular}

Перше покоління очищених препаратів ФНП отримували завдяки культивуванню імунокомпетентних тваринних або людських мононуклеарних клітин (табл. 3), стимулюючи утворення ФНП бактеріальними ліпополісахаридами (ЛПС) або рослинним фітогемаглютеніном (ФГА) [6; 7; 8]. Але отримання препарату таким способом $є$ довготривалим і трудомістким, крім того, вказані клітини-продуценти не забезпечують високий вихід цільового продукту.

Таблиця 3. Індукція синтезу ФНП у мононуклеарних клітинах людини

\begin{tabular}{|c|c|c|c|}
\hline Тип клітин & Індуктор & $\begin{array}{c}\text { Концентрація } \\
\text { індуктора, мкг/мл }\end{array}$ & $\begin{array}{c}\text { Кількість ФНП, } \\
\text { мг/мл }\end{array}$ \\
\hline \multirow{3}{*}{$\begin{array}{c}\text { Мононуклеарні } \\
\text { клітини плевральної } \\
\text { рідини людини }\end{array}$} & ЛПС & 0,1 & $7,2 \cdot 10^{-1}$ \\
\hline & Рицин & $5-10 п \mathrm{M}$ & $8,0 \cdot 10^{-1}$ \\
\hline & Ліпоарабінноманнан & 10 & $4,0 \cdot 10^{-1}$ \\
\hline \multirow{9}{*}{$\begin{array}{c}\text { Мононуклеарні } \\
\text { клітини переферійної } \\
\text { крові }\end{array}$} & Конканавалін А & 5 & $4,4 \cdot 10^{-1}$ \\
\hline & Полігідроксиалканоати & 10 & $19,4 \cdot 10^{-1}$ \\
\hline & Staphylococcus aureus Cowan & 10 & $58,0 \cdot 10^{-1}$ \\
\hline & Мікогенний порошок & 5 & $22,1 \cdot 10^{-1}$ \\
\hline & $\Phi Г А$ & 20 & $8,87 \cdot 10^{-1}$ \\
\hline & Антиген Hirudo verbana & 125 & $13,15 \cdot 10^{-1}$ \\
\hline & Антиген $H$. medicinalis & 125 & $15,59 \cdot 10^{-1}$ \\
\hline & Антиген Helleborus orientalis & 125 & $14,16 \cdot 10^{-1}$ \\
\hline & Антиген Eisenia fetida & 125 & $2,09 \cdot 10^{-1}$ \\
\hline
\end{tabular}


Серед прокаріотичних клітин найбільш поширеними продуцентами рекомбінантного фактора некрозу пухлин $\epsilon$ різні штами $E$. coli [9]. Зокрема, створено штам E. coli C600/pBV-TRAIL, за 30 год культивування якого вдається отримати до 1600 мг/л ФНП [10].

Для покращення біологічних властивостей ФНП, підвищення його активності та зменшення токсичності розробляють і досліджують різні модифікації даного цитокіну. Так, в [11] автори досліджували можливість поєднання доксорубіцину (антрацикліновий антибіотик, що використовується у хіміотерапії ракових пухлин) з ФНП. При цьому на поверхню наночасток карбонату кальцію нашаровували доксорубіцин, після чого пошарово наносили комплекс ФНП TRAIL-альгінат (ФНП-зв'язаний апоптоз-індукуючий ліганд $з$ альгінатом), формуючи таким чином лікарську форму терапевничного протиракового засобу. У такій лікарській формі саме ФHП-TRAIL залишався активною частиною даного комплексу і викликав апоптоз ракових клітин. Звільнення доксорубіцину також призводило до ціленаправленого лізису пухлинних клітин [11].

$€$ дані щодо можливості поєднання ФНП з фрагментами антитіл. Зокрема, досліджували нанокомплекс ФНП, що виступав у ролі полімерного ядра, оточеного ліпідною оболонкою $з$ одноланцюговими фрагментами антигензв'язуючої області (Fv) антитіл. Комплекси стабілізували поліетиленгліколем (ПЕГ). Використання фрагментів антигензв'язуючої області антитіл проти стромального пухлинного маркерного білка активації фібробластів (FAP) давало змогу нанокомплексам специфічно зв'язуватись з FAP-експресуючими клітинами. Таким чином, за допомогою ліпосомального капсулювання наночастинки, що несуть біологічно активні молекули, які підлягають неселективному поглинанню і мають активність стосовно різних клітин і тканин, можуть бути перетворені в клітинно-специфічні композитні мішені, які проявляють селективну активність стосовно антиген-позитивної клітини-мішені [12].

Іншим прикладом модифікації $\epsilon$ хімічна кон'югація поліетиленгліколю 3 ФНП за рахунок сукцинімідильного зв'язування з аміногрупами лізину в молекулі ФНП. У даному комплексі виявили зменшення токсичності ФНП, підвищення його протипухлинної активності (у 4-100 разів залежно від відсотка зв'язаних залишків лізину з ПЕГ, в межах від 29 до 56\%) на моделі мишачої М-2 фібросаркоми [13].

ФНП можна модифікувати 3 використанням наночасток металів, зокрема золота. Так, на поверхні наночасток золота (30 нм) адсорбували молекули фактора некрозу пухлин, стабілізовані поліетиленгліколем. Застосування даних наночасток досліджували на моделі карциноми нирок з використанням радіочастотної амбляції. Нанокомпозит ФНП з наночастками золота збільшував зону дії абляції, що підтверджує можливість його використання у лікуванні пухлин з використанням радіочастотної амбляції [14]. В іншому дослідженні підтверджена можливість неспецифічного зв'язування ФНП з цитратстабілізованими наночастками золота. Дана модифікація захищає фактор некрозу пухлин від адсорбції специфічних анти-ФНП антитіл [15].

Варто зазначити, що у більшості випадків дослідники використовували поліетиленгліколь для утворення комплексних нанокомпозитів. Процес 
поєднання нативної молекули лікарського препарату з ПЕГ отримав назву пегілювання. Подібна хімічна модифікація фармакологічних препаратів пептидної структури спрямована на поліпшення їх переносимості, зниження імуногенності та підвищення періоду напіврозпаду.

Однак було б невірним вважати, що пегілювання несе тільки позитивний результат, а ПЕГ-кон'югати мають лише переваги над нативними пептидами. До основних недоліків пегільованих пептидів відноситься можливе зменшення активності пептиду або уповільнення елімінації, що пов'язане з вибором неправильного розміру або структури ПЕГ. Також варто сказати, що всі види ПЕГ, включаючи їх етери, мають певну окисну активність (особливо при температурі вище $50^{\circ} \mathrm{C}$ ) завдяки наявності пероксидних домішок і вторинних продуктів, утворених при автоокисненні. Тому ПЕГ має хоч і низьку, але певну токсичність. Серед недоліків процедури пегілювання $є$ ії складність, а також тривалість у часі, що робить ії відносно дорогою.

\section{Висновки}

Нині ведуться розробки і дослідження нових форм ФНП з метою створення на їх основі ефективних протипухлинних засобів. Більшість досліджень щодо модифікації фактора некрозу пухлин спрямовані на розробку ефективної лікарської форми для зручної доставки терапевтичного цитокіну до місця дії, або для збільшення біодоступності ФНП для організму. Все це свідчить про необхідність і перспективність подальших досліджень щодо створення нових протипухлинних препаратів на основі ФНП з покращеними терапевтичними властивостями.

\section{Література}

1. Кевра М.К. Фактор некроза опухолей: регуляция продукции в организме / М.К. Кевра // Медицинские новости. — 1995. - № 6.- С. 12-25.

2. Grivennikov S.I. Immunity, inflammation and cancer/ S.I. Grivennikov, F.R. Greten, M. Karin // Elsevier Inc. - 2010. - Vol. 140 - P. 883-899.

3. Recombinant production of bioactive human TNF-alpha by SUMO-fusion system - high yields from shake-flask culture / A. Hoffmann, M.Q. Müller, M. Gloser et al. // Protein Expr. Purif. - 2010. - Vol. 72(2). - P. 238-243.

4. Expression of a functional human tumor necrosis factor- $\alpha$ (hTNF- $\alpha$ ) in yeast Saccharomyces cerevisiae / Seung-Moon Park, Ae-Young Mo, Yong-Suk Jang, et al. // Biotechnol. and Biopr. Eng. - 2004 - Vol. 9. - P. 292-296.

5. Пат. № 2556816 РФ. Штамм клеток яичников китайского хомячка - продуцент рекомбинантного антитела против фактора некроза опухоли альфа человека / А.В. Петров, А.С. Симбирцев, А.М. Ищенко и др. - опубл. 20.01.2013.

6. Cytokine production in cell culture by peripheral blood mononuclear cells from immunocompetent hosts / R.K. Katial, D. Sachanandani, C. Pinney et al. // Clin.Diagn.Lab.Immunol. 1998. - Vol. 5(1) - P. 78-81.

7. Tumor necrosis factor (TNF) gene polymorphism influences TNF- $\alpha$ production in lipopolysaccharide (LPS)-stimulated whole blood cell culture in healthy humans / E. Louis, D. Franchimont, A. Piron et al. // Clin.Exp.Immunol. - 1998. - Vol. 113 - P. 401- 406.

8. Синтез фактора некроза опухоли- $\alpha$, апоптоз и некроз мононуклеаров, стимулированных растительным митогеном и антигенами кольчецов / А.С. Прилуцкий, А.К. Фролов, Д.А. Лесниченко и др. // Вісник Запорізького національного університету. — 2015. № 2 - С. $166-174$. 
9. Скроцька O.I. Рекомбінантні організми як перспективні продуценти фактора некрозу пухлин / О.І. Скроцька, Є.В. Харченко // Наукові праці Національного університету харчових технологій. - 2017. - Т. 23, № 1. - С. $42-48$.

10. Improvement of expression level and bioactivity of tumor necrisis factor-related apoptosis-inducing ligand (Apo2L/TRAIL) by a novel zinc ion feeding strategy / Ai-You Sun, Ya-Ling Shen, Ji-Cheng Yin et al. // Biotech. Lett. — 2006. — Vol. 28. - P. 1215-1219.

11. Wei Cui Fabrication of tumor necrosis factor apoptosis inducing ligand (TRAIL) / ALG modified $\mathrm{CaCO} 3$ as drug carriers with the function of tumor selective recognition / Wei Cui, Yue Cui, Jie, Junbai Li // J. Mater. Chem. B. - 2013. - Vol. 1. — P. 1326-1332.

12. Targeted lipid-coated nanoparticles: Delivery of tumor necrosis factor-functionalized particles to tumor cells / S.K.E. Messerschmidt, A. Musyanovych, M. Altvater et al. // Journal of Controlled Release. - 2009. - Vol. 137 (1). - P. 69-77.

13. Molecular design of hybrid tumour necrosis factor alpha with polyethylene glycol increases its anti-tumour potency / Y. Tsutsumi, T. Kihiral, S. Tsunoda et al. // Brit. Journ. of Canc. - 1995. - Vol. 71. - P. 963-968.

14. Use of Tumor necrosis factor-alpha-coated gold nanoparticles to enhance radiofrequency ablation in a translational model of renal tumors / P.R. Nardi, T. Thekke-Adiyat, R. Goel et al. // Elsevier Inc. - 2010. - Vol. 76(2). - P. 494- 498.

15. Tumor necrosis factor interaction with gold nanoparticles / D. Tsai, S. Elzey, F. Delrio et al. // Nanoscale. — 2012. — Vol. 4(10). - P. 3208-3218. 